\title{
THE EFFECT OF CAPITAL STRUCTURE ON CASH DIVIDEND POLICY WITH LIQUIDITY AS MODERATION IN MINING COMPANIES ON IDX 2015-2019
}

\author{
Lissa Mariyana \\ Faculty of Economics and Business, Padjadjaran University, Bandung \\ Corresponding author: lissamariyana24@gmail.com
}

\begin{abstract}
A company will be assessed for its resilience in surviving as an economy; one of them is a mining company required to have a stock of funds. This research involves mining companies because the mining sector has experienced a decline and has had the slowest growth since 2013. This occurs because the price of global mining commodities is experiencing a price decline following the decline in demand from China and other developing countries, as well as the existence of the Mineral and Coal Law policy, which also suppresses the growth of the mining sector internally and has the potential to be a liquidity value for a company. This study will measure the capital structure through IOS, company size, growth rate, profitability, and business risk, affecting the cash dividend policy with liquidity as a moderating variable in mining companies listed in 2015 2019. The research method used is associative quantitative with a sample of 41 mining sector companies listed on the Indonesia Stock Exchange during the 2015-2019 period. The type of data used in this study is secondary data which includes data from the financial statements of mining companies with analysis using descriptive statistics. The research results show that simultaneously, IOS, Company Size, Growth Rate, Profitability (ROI), and Business Risk significantly affect cash dividend policy (DEV) through liquidity moderation.
\end{abstract}

Keywords: Capital Structure, Cash Dividend, Liquidity, Mining Company, BEI.

\section{Introduction}

The rapid development of the business world and the economy has created increasingly intense competition between companies. One of the factors that make a company competitive in the long run is its Investment Opportunity Set (Ios). Thus, the decision on the sources of funds to strengthen a company's capital structure cannot be seen as a straightforward decision but has substantial implications for what will happen in the future. So that the company is required to be able to create an optimal capital structure by collecting funds both from within and from outside the company. Management must consider the pros and cons of funding decisions whether the company uses foreign capital (debt) or its capital.

Company size can be seen from the company's capital, where the capital structure can be measured by the Debt to Equity Ratio (DER) and Debt to Assets Ratio (DAR). DER compares total debt and equity in company funding and shows the company's own capital ability to fulfill all of its obligations (Syahyunan, 2015). If the DER is more than one, it indicates that the company uses more debt than its capital (equity) and causes its risk to increase. Therefore, investors tend to be more interested in a DER level of less than one to decide dividend policy. DAR is a comparison between total debt and total assets in company funding. This ratio is used to measure how much the company's assets are financed by debt. The higher the DAR, the greater the amount of loan capital used to invest in assets to generate profits for the company.

Company size is another essential factor that is considered in the decision to determine the capital structure. Company size is the company's size seen from the amount of equity value, company value, or the results of the total asset value of a company (Riyanto, 2018). The bigger the company, the greater the tendency to use foreign capital. Because large companies must have significant funds to finance their activities and fulfill these funding needs, one alternative that can be done is to use debt, including mining companies.

Mining companies have different characteristics and characteristics from other sectors. In the mining sector, investment costs are considerable, long-term, hazardous, and high uncertainty makes funding a problem related to company development. Mining companies also require enormous capital to conduct natural resource investigations and the development of the mining sector. So that many mining companies have entered the capital market to obtain investment and strengthen their financial position. Mining companies have experienced a decline and have had the slowest growth since 2013 to date. This occurs because the price of global mining commodities is experiencing a price decline following the decline in demand from China and other developing countries, as well as the existence of the Mineral and Coal Law policy, which also suppresses the growth of the mining sector internally and has the potential to be a liquidity value for a company.

Dividend policy has a relationship with agency costs which have become the focus to explain dividend payments can be used to control agency costs of the company. If these conditions are not healthy for the company, the profit earned is not as expected, less liquid, and the company's cash flow is heavy. Usually, companies tend not to pay dividends in cash dividends and replace them with other types of dividends such 
as dividends or property dividends. Even companies can choose to hold profits and not pay dividends at all. Management's goal of distributing stock dividends is to increase and maximize the market value of shares. Increase the prosperity of shareholders. There are even some shareholders who receive stock dividends, reinvest the dividends they receive into the company.

Based on this description, the research aims to answer whether the capital structure through IOS, company size, growth rate, profitability, and business risk affect the cash dividend policy with liquidity as a moderating variable in mining companies listed in 2015-2019?

\section{Literature Review \\ Theoretical Framework}

Every investment activity undertaken by a company will require funding. Therefore, if the internal funds (own capital) are insufficient, the company must seek funds from outside sources. Indeed, it would be ideal if the company could use internal funds to invest. However, in reality, investments generally require large amounts of funds, and internal funds owned by companies are often insufficient to finance these investments.

The first modern capital structure theory is Modigliani and Miller's theory (MM theory). MM argues that the capital structure does not affect firm value. MM put forward several assumptions to build their theory, namely no agency cost, no tax, investors can owe the same interest rate as the company, investors have the same information as management regarding the company's prospects, no bankruptcy fees, Earning Before Interest and Taxed (EBIT) is not affected by the use of debt, investors are price-takers. In the event of bankruptcy, the assets can be sold at market value.

In addition, there is a trade-off theory which states that the company will owe up to a certain level of debt, where the tax savings (tax shields) from additional debt are the same as the cost of financial distress. The cost of financial distress (financial distress) is the cost of bankruptcy (bankruptcy cost) or reorganization and agency costs that increase due to a decline in the credibility of a company. The trade-off theory in determining the optimal capital structure includes several factors, including taxes, agency costs, and financial distress costs. Still, it maintains the assumption of market efficiency and symmetric information as balancing and benefits of using debt. The optimal level of debt is achieved when the tax savings (tax shields) reach the maximum amount against the cost of financial distress. The trade-off theory implies that managers will think about the trade-off between tax savings and the cost of financial difficulties in determining the capital structure.

Company size is a description of the company's financial capability in a certain period. Company size describes the size of a company. The company's size can be determined based on total sales, total assets, the average level of sales, and average total assets. Large companies will find it easier to obtain loans than small companies. Company size is one of the factors that companies consider in determining their capital structure. The greater the size of the company, the greater the funds that will be issued by the company, either from debt or equity policies in maintaining or developing the company. The larger the company size, the greater the tendency to use foreign capital. This is because large companies also need significant funds to support their operations, and one alternative to fulfill it is foreign capital if their capital is insufficient.

According to the signaling theory, companies that increase debt can be seen as confident about the company's prospects in the future. Large companies will be more willing to issue or issue new shares to meet their funding needs when compared to small companies. Therefore, large companies will find it easier to obtain capital in the capital market than small companies. Because the ease of access means large companies have greater flexibility as well. Empirical evidence states that company size is positively related to the ratio of debt to book value of equity or debt to book value of equity ratio.

\section{Conceptual Framework}

Companies with sufficient assets to be used as loan collateral tend to use debt quite a lot. General assets that can be used by many companies make good collateral, while assets that are used only for specific purposes are not very good as collateral. The larger the company size, the greater the tendency to use foreign capital. This is because large companies also need large amounts of funds to support their operations. One of the alternative means of fulfilling them is foreign capital if their capital is not sufficient.

The cash dividend definition is a dividend paid in cash to shareholders following the percentage of share ownership. Either by transfer or check paper. A cash dividend or also known as a cash dividend (cash dividend), is a dividend payment that is most commonly made and is paid regularly, either annually or six months. The size of the cash dividend can be influenced by the level of profit or profitability of the company, the condition of the company's liquidity, and the company's cash flow. There have even been cases of companies paying dividends that exceed the net income generated by the company.

Meanwhile, dividend payments can also be explained by the dividend life cycle theory that companies that have developed and can grow into adulthood can generate stable profits then decrease systemic risk. The company will begin to pay cash dividends to distribute income to the shareholders. Stock valuation is an essential factor in the company's financial function. Share value can be a measure for determining investment decisions in share capital in a company. 
Dividend changes provide information about the manager's expectations of current and future earnings. Investors know that management is trying to keep its dividends stable, so if the company changes its dividends, that is a signal. Dividend changes provide information to investors who in the capital market do not know company information about the company's condition to avoid information asymmetry. The value of a company is only determined by its fundamental ability to generate profits and its business risk; or in other words, the company's dividend policy does not affect either the company value or its capital costs. Shareholders (shareholders) will make more efforts to maximize their wealth, while managers will maximize the rewards from managing the company (additional income and a good reputation).

The conceptual framework of this research is described as:

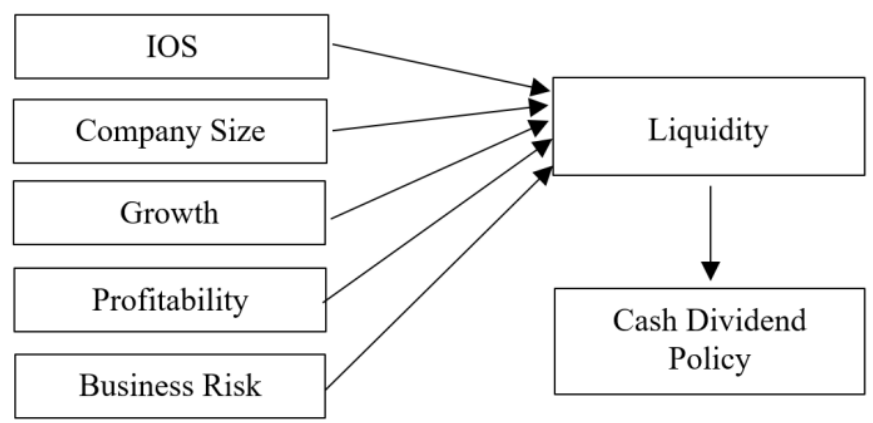

\section{Research Hypothesis}

Figure 1. Conceptual Framework

Based on the literature review, previous research, and conceptual framework, the hypothesis of this research is that ios, company size, growth rate, profitability, and business risk significantly affect liquidation and cash dividend policy on mining sector companies Indonesia Stock Exchange.

\section{Research Method}

This research was conducted in the mining sector, listed on the Indonesia Stock Exchange, in 2015-2019. Amid the increasingly fluctuating global economic conditions in the last few years, funding has become a significant problem that mining companies must face.

This type of research is associative research, which aims to determine the effect or relationship between two or more variables. This research is quantitative, namely data in numbers and based on the source, secondary data, namely data obtained or collected and compiled by previous studies or published by various other agencies.

The operational limitations in this study are as follows:

1. Objects used in this study are mining companies listed on the IDX from 2015 to 2019.

2. The independent variable in this study is the model structure as measured by Ios, Company Size, Growth Rate, Profitability, and Business Risk.

3. The dependent variable in this research is cash dividend policy through moderation of mining company liquidity.

The population in this study were all mining sector companies listed on the Indonesia Stock Exchange during the 2015-2019 period. In detail, there are 41 (forty-one) companies, and the sample used in this study is 11 (eleven) companies, which are taken using predetermined criteria, namely

1. All mining sector companies listed on the Indonesia Stock Exchange for 2015-2019.

2. The company publishes audited financial reports wholly and consistently from 2015-2019.

3. Companies that did not make business changes or sector transfers during the 2015-2019 period.

4. Companies whose financial statements are described in Rupiah monetary units.

5. The overall measurement scale of these variables will use the ratio.

The research sample includes:

Table 1. List of mining companies as samples

\begin{tabular}{lll}
\hline \multicolumn{1}{c}{ No } & \multicolumn{1}{c}{ Kode } & \multicolumn{1}{c}{ Nama } \\
\hline 1 & ATPK & Bara Jaya Internasional Tbk \\
\hline 2 & PKPK & Perdana Karya Perkasa Tbk \\
\hline 3 & PTBA & Tambang Batubara Bukit Asam Tbk \\
\hline 4 & ELSA & Elnusa Tbk \\
\hline 5 & RUIS & Radiant Utama Interinsco Tbk \\
\hline 6 & ANTM & Aneka Tambang Tbk \\
\hline 7 & CITA & Cita Mineral Investindo Tbk \\
\hline 9 & DKFT & Central Omega Resources Tbk \\
\hline 10 & TINS & Timah Persero Tbk \\
\hline 11 & CTTH & Citatah Tbk \\
\hline
\end{tabular}


The type of data used in this study is secondary data which includes data from mining company financial reports using the literature study method, namely by examining various literature such as books. Reference books, scientific papers, journals, papers, and other sources related to research. The analytical method used in this research is to perform quantitative analysis expressed by numbers, which in the calculation uses statistical methods assisted by statistical data management program E-views with descriptive statistical analysis.

\section{Result and Discussion \\ Reseach Result}

The research results will be analyzed statistically descriptively to determine the description of data seen from the maximum value, minimum value, average value (mean), and standard deviation value.

In this study, the variables used in the calculation of descriptive statistics are IOS (IOS), Company Size (SIZE), Growth Rate (GROWTH), Profitability (ROI), Business Risk (B_RISK), Liquidation (LIK), and Cash Dividend Policy (DEV).

Table 2. Descriptive Statistics Sample Mining Company 11

\begin{tabular}{lrrrrrrr}
\hline & \multicolumn{1}{c}{ IOS } & \multicolumn{1}{c}{ SIZE } & \multicolumn{1}{c}{ GR } & \multicolumn{1}{c}{ ROI } & \multicolumn{1}{c}{ BRI } & \multicolumn{1}{c}{ LIK } & \multicolumn{1}{c}{ DEV } \\
\hline Mean & 0.281270 & 28.36967 & 0.281726 & -0.009701 & 25.27234 & 1.059252 & 0.448265 \\
\hline Max & 0.764070 & 31.04404 & 8.874321 & 0.211430 & 28.53183 & 3.987200 & 0.799490 \\
\hline Min & 0.005180 & 25.77947 & -0.438519 & 0.721330 & 20.77289 & 0.042450 & 0.040720 \\
\hline Std.Dev & 0.180784 & 1.551450 & 1.359594 & 0.151214 & 1.982428 & 0.876166 & 0.172410 \\
\hline f & 11 & 11 & 11 & 11 & 11 & 11 & 11 \\
\hline
\end{tabular}

Table 2 shows that the amount of data used in this study is 11 (eleven) samples of data taken from the annual publication financial reports of mining sector companies in 2015-2019.

Next will be measured through panel data, where panel data are combined data from time-series data and cross-section data. To estimate model parameters with panel data, several techniques are offered, namely: Common Effect Model (CEM) ) or Pooled Least Square (PLS), Fixed Effect Model (FEM), and Random Effect Model (REM).

Determine whether the Common Effect Model (CEM) or Fixed Effect Model (FEM) estimation model in forming a regression model, the Chow test can be used. The results of the Chow test for the dependent variable can be seen in the following table:

Table 3. Chow test 1

\begin{tabular}{llrl}
\hline Effects Test & Statistic & \multicolumn{1}{c}{ d.f } & Prob. \\
\hline Cross-section F & 11.059705 & $(10,28)$ & 0.0000 \\
\hline Cross-section Chi-square & 70.372118 & 10 & 0.0000 \\
\hline
\end{tabular}

Based on the results of the Chow test from table 3, it is known that the probability value is 0.0000 . Because the probability value is $0.0000<0.05$, the estimation model used is the fixed effect model (FEM) model.

Table 4. Chow test 2

\begin{tabular}{lcrc}
\hline Effects Test & Statistic & \multicolumn{1}{c}{ d.f } & Prob. \\
\hline Cross-section F & 9.776746 & $(10,28)$ & 0.0000 \\
\hline Cross-section Chi-square & 66.098127 & 10 & 0.0000 \\
\hline
\end{tabular}

Based on the results of the Chow test in table 4, it is known that the probability value is 0.0000 . Because the probability value is $0.0000<0.05$, the estimation model used is the Fixed Effect Model (FEM).

\section{Multiple Linear Regression Analysis Panel Data Multiple}

Multiple linear regression analysis of panel data is used to determine the effect of the variable Asset Structure, Company Size, Growth Rate, Profitability, and Business Risk on Debt to Equity Ratio and Debt to Assets Ratio in the mining sector companies. Multiple linear regression testing of panel data is carried out to find the relationship between the independent and dependent variables through 1 . The effect of IOS, Company Size, Growth Rate, Profitability, and Business Risk on Cash Dividend Policy (DEV) through liquidation moderation (LIK). 
Table 5. Multiple Linear Regression Panel Data

\begin{tabular}{lrrrr}
\hline Variable & Coefficient & Std.Error & \multicolumn{1}{l}{ t-Stat } & \multicolumn{1}{l}{ Prob. } \\
\hline IOS & -0.231081 & 0.118991 & -1.94199 & 0.0623 \\
\hline SIZE & 7.730992 & 8.369576 & 0.923702 & 0.3635 \\
\hline GR & 0.001381 & 0.043250 & 0.031926 & 0.9748 \\
\hline ROI & 0.036326 & 0.050719 & 0.716224 & 0.4798 \\
\hline BRI & 7.698530 & 2.470322 & 3.116407 & 0.0042 \\
\hline LIK & -51.14698 & 27.54179 & -1.85706 & 0.0739 \\
\hline
\end{tabular}

Based on data management in Table 5 in the column coefficient obtained regression model to influence Asset Structure, Company Size, Growth Rate, Profitability, and Business Risk to Debt to Equity Ratio as follows: Y1 $=\beta 0+\beta 1 X 1$ it $+\beta 2$ X2it $+\beta 3$ X3it $+\beta 4$ X4it $+\beta 5$ X5it $+\varepsilon$ Thus, the multiple linear regression equation for panel data is as follows: DEV $=-51,146 \mathrm{LIK}-0.231 \mathrm{IOS}+7,730 \mathrm{SIZE}+0.001 \mathrm{GROWTH}+$ 0.036 ROI + 7,698 B_RISK.

In this study, the normality test of the residuals used the Jarque-Bera (JB) test. In this study, the level of significance used is $\alpha=0.05$. The basis for decision making is to look at the probability number from the JB statistic, provided that if the probability value is $p p \geq 0.05$, the normality assumption is fulfilled, but if the probability $<0.05$, the normality assumption is not fulfilled.

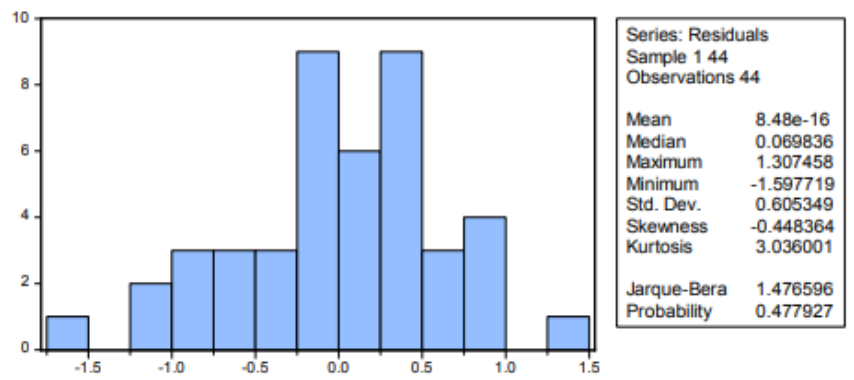

Figure 2. Normality Test with the Jarque-Bera Test

Based on Figure 2, it is known that the probability value of the JB statistic is 0.477927 . Because the probability value $p p$, which is 0.477927 , is greater than the significance level, which is 0.05 . This means that the assumption of normality is fulfilled.

In this study, the symptoms of multicollinearity can be seen from the correlation value between variables contained in the correlation matrix. If the correlation coefficient between each independent variable is more significant than 0.9 , then multicollinearity occurs.

Table 6. Correlation Matrices Test Multicollinearity with

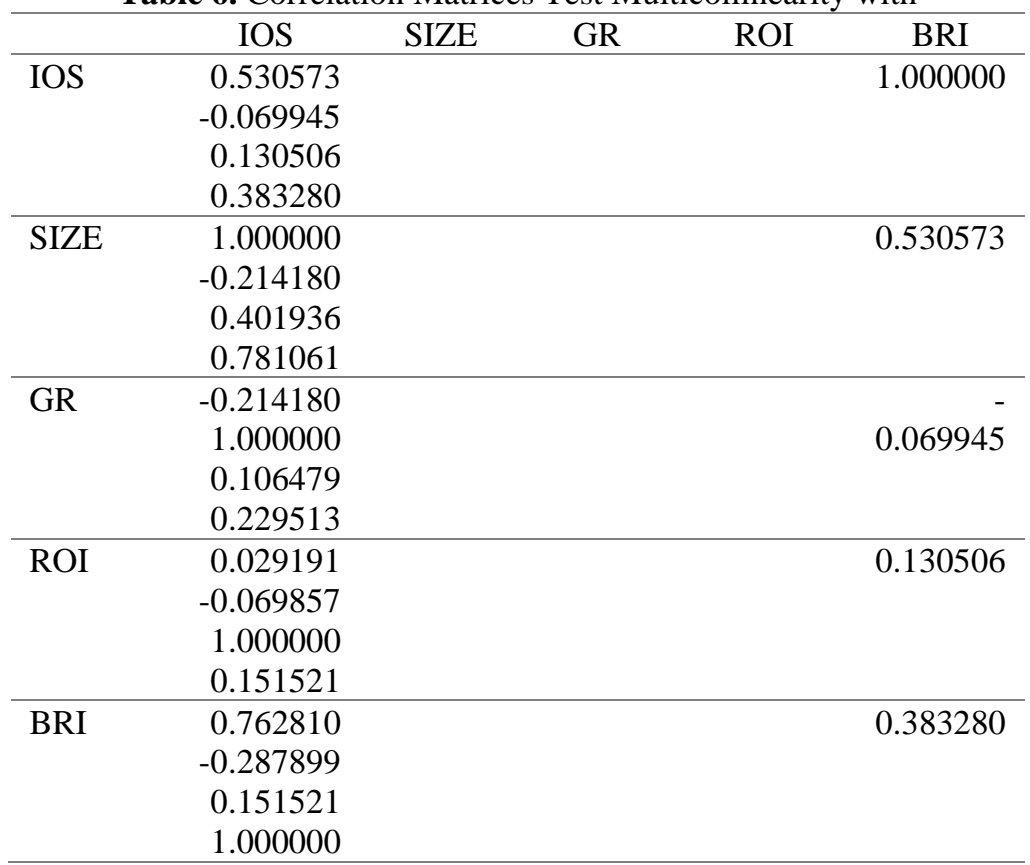

The multicollinearity test results in Table 4 can be concluded that there are no multicollinearity symptoms between the independent variables. This is because the correlation value between the independent variables is not more than 0.9 .

Assumptions regarding independence from residuals (non-autocorrelation) can be tested using the Durbin-Watson test. In the DW test, there is no autocorrelation if the value is $-2 \leq \mathrm{DW} \leq 2$ 
Table 7. Autocorrelation test with the Durbin-Watson

\begin{tabular}{llll}
\hline Log-likelihood & test -39.84176 & Hannan-Quinn criteria & 2.173943 \\
& & Durbin-Watson stat & 1.069143 \\
\hline
\end{tabular}

Based on Table 5, the value of the Durbin-Watson statistic is 1, 069143. Note that since the DurbinWatson statistic value lies between -2 and 2 , i.e., $-2 \leq 1.069143 \leq 2$, the non-autocorrelation assumption is fulfilled. In other words, there was no high autocorrelation symptom at the residuals

The purpose of conducting the heteroscedasticity test is to test whether there is a variance difference from the known residuals of the independent variables in a regression model. To detect the presence or absence of heteroscedasticity symptoms, the Breusch-Pagan test can be done.

Table 8. Heteroscedasticity Test (Breusch-Pagan Test)

\begin{tabular}{lllr}
\hline F-statistic & 1.236710 & Prob. F () & $5,380.3112$ \\
\hline Obs * R-squared & 6.157863 & Prob. Chi-Square (5) & 0.2912 \\
\hline Scaled explained SS & 4.675627 & Prob. Chi-Square (5) & 0.4567 \\
\hline
\end{tabular}

Given the value of Prob. Chi-Square of Obs * R-Squared is 0.2912>0.05, so the assumption of heteroscedasticity is not fulfilled. In other words, there were no symptoms of high heteroscedasticity at the residuals.

The test of Goodness of Fit or the model's feasibility test is used to measure the accuracy of the sample regression function in estimating the actual value. Statistically, the Test of Goodness of Fit can be done by measuring the coefficient of determination (R2), the F statistical value, and the $t$ statistical value

Table 9. The value of a statistical coefficient of determination, $F$ test, and t-test

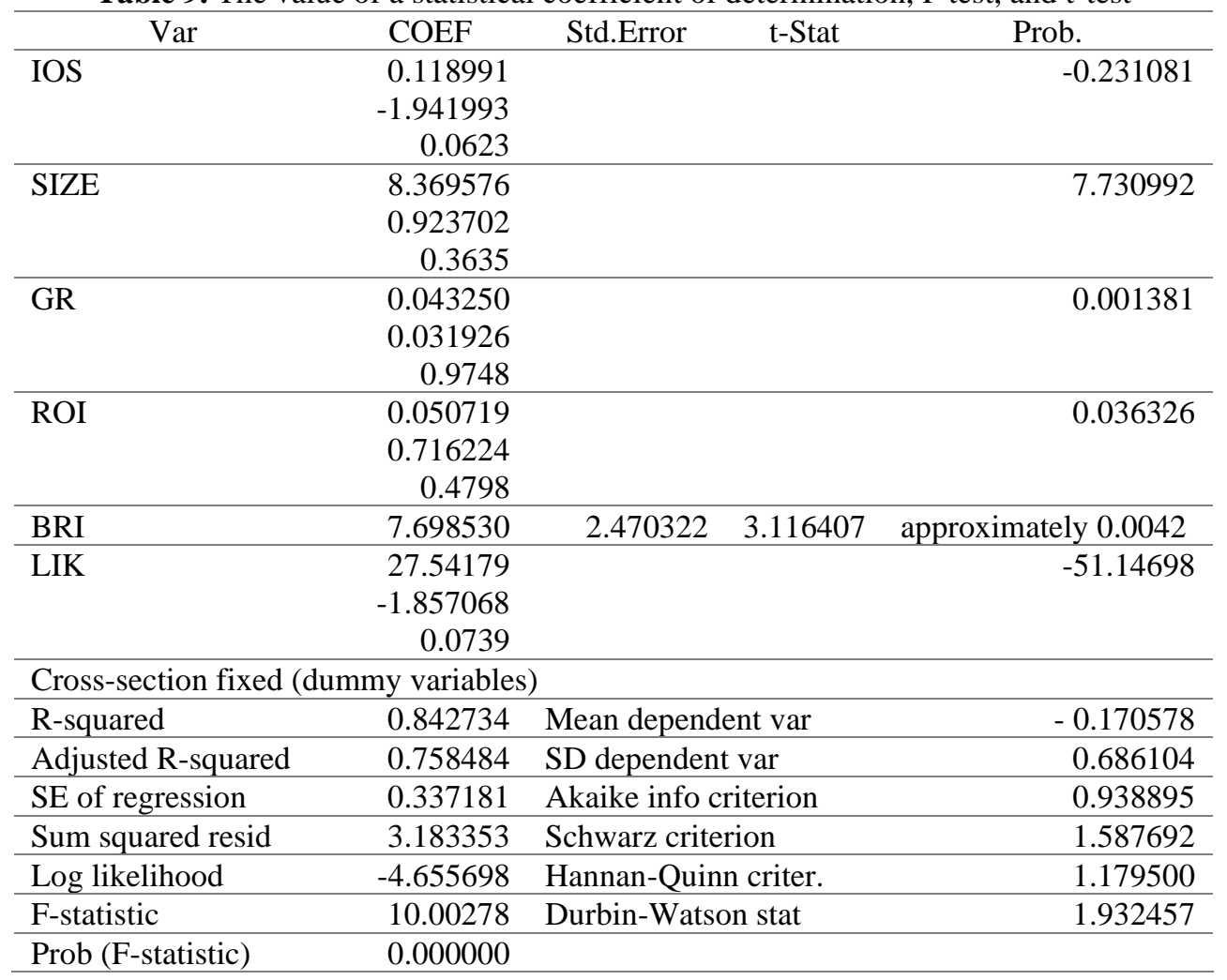

The coefficient of determination (R2) function to see the extent to which the independent variables can explain the dependent variable. The coefficient of determination is between 0 and $1(0 \leq R 2 \leq 1)$. Suppose the coefficient of determination is close to one. In that case, it means that the independent variable provides almost all the information needed to predict the dependent variable. In contrast, the coefficient of determination which is close to zero means that the ability of the independent variables to explain the dependent variable is minimal.

Based on Table 7, note the value of the coefficient of determination (R2)of 0.8427. This value means that IOS, SIZE, GROWTH, ROI, and B_RISK can influence or explain DER simultaneously at 84.27\%, while the remaining $15.73 \%$ is influenced by other factors not included in this study.

Based on the results of the F test calculated in Table 7, it is known that the F value is calculated 10.00278 with a significance level of 0.00000 , while the Fvaluetable based on df $1=\mathrm{k}-1=6$ and df $2=\mathrm{n}-\mathrm{k}=37$ is 
2.35618 with a level significance of 0.05 . Because F count is greater than Ftable (10.00278> 2.35618) and the level of significance $(\alpha) 0.00000<0.05$, then Ha is accepted, which means that all independent variables, namely IOS, SIZE, GROWTH, ROI, and B_RISK, simultaneously have a significant effect on the DEV variable.

\section{Discussion}

The research findings then provide a discussion, namely:

1. The partial test results (t-test) show that IOS has a negative and insignificant effect on cash dividend policy (DEV) through moderation of mining company liquidity.

2. The partial test results (t-test) show that Company Size (SIZE) has a positive and insignificant effect on the cash dividend policy (DEV) through moderating liquidity of mining companies. These results indicate that the larger the size of the mining company, the greater the tendency to use external funds. This is because large companies have significant funding needs, and one of the fulfillment of the required funds is using external funds (debt). The larger the company's size, the easier it is for the company to obtain funds from outside the company.

3. The partial test results (t-test) show that the growth rate (GROWTH) has a positive and insignificant effect on the cash dividend policy (DEV) through moderating the liquidity of mining companies. The asset growth rate has a positive effect, and it means that companies with high growth rates have relatively more significant capital requirements, so companies choose to use external funds. This is because companies with high growth affect company funding policies. A company with a high asset growth rate will operate at a higher rate, thus requiring additional costs.

4. The partial test results (t-test) show that profitability (ROI) has a positive and insignificant effect on cash dividend policy (DEV) through moderation of mining company liquidity. This shows that the greater the profitability (ROI) obtained by the company, the greater the cash dividend policy (DEV) by moderating mining companies' liquidity. Companies with high profitability will prevent the company from going bankrupt and have better investment opportunities.

5. The partial test results (t-test) show that Business Risk (B_RISK) has a positive and significant effect on cash dividend policy (DEV) through moderating liquidity of mining companies. This shows that the higher the business risk, the higher the cash dividend policy (DEV) through moderating liquidity of mining companies. There is a positive influence of business risk on the capital structure due to the high opportunities for profit growth in the mining sector. This condition results in the company having a large enough capacity to bear the risks arising from increased debt to increase investment and production capacity.

\section{Conclusion}

Based on data analysis and discussion, the conclusions obtained in this study show that simultaneously, IOS, Company Size, Growth Rate, Profitability (ROI), and Business Risk have a significant effect on cash dividend policy (DEV) moderation. Liquidity.

Partially business risk has a significant positive effect on cash dividend policy (DEV) through liquidity moderation. Meanwhile, company size, growth rate, and profitability (ROI) have a positive and insignificant effect on the cash dividend policy (DEV) through liquidity moderation. Moreover, IOS has a negative and insignificant effect on the cash dividend policy (DEV) through moderating liquidity in mining sector companies listed on the Indonesia Stock Exchange.

Based on the study results, the research provides several suggestions, namely that the management of mining companies must pay attention to the variables of business risk, profitability, ios, company size, and growth rate in considering and determining the direction of the company's capital structure policy. However, management should not ignore other variables that were not examined in this study. This is intended to facilitate the management of mining sector companies to achieve the level of cash dividend policy (DEV) by moderating optimal liquidity for the company. Mining sector companies have high business risks, the funds needed by companies are also high. The use of debt is an option for funding. Mining companies that can generate high profits should reduce foreign capital (debt) and switch to using funding from their capital. This can reduce potential risks, given that mining companies have a high level of risk and uncertainty.

\section{References}

Acaravci, S. K. (2015). "The Determinants of Capital Structure: Evidence From The Turkish Manufacturing Sector." International Journal of Economics and Financial Issues, Vol. 5, No.1, pp.158-171.

Agustini, T., dan Budiyanto. (2015). "Pengaruh Struktur Aktiva, Profitabilitas dan Ukuran Perusahaan Terhadap Struktur Modal". Jurnal Ilmu dan Riset Manajemen, Vol. 4, No. 8, pp.1-16.

Brigham, E. F., end Houston, J. F. (2011). Dasar-dasar Manajemen Keuangan. (Ahli Bahasa: Ali Akbar Yulianto). Edisi Kedua. Jakarta: Salemba Empat

Hang, N. T., end Hung, R. J. (2016). "Determinants of Capital Structure of The Listed Companies on Vietnam Stock Market." The International Journal of Business \& Management, Vol. 4, No. 6, pp.27-35. 
Indrajaya, G. Herlina, dan Setiadi R. (2011). "Pengaruh Struktur Aktiva, Ukuran perusahaan, Tingkat Pertumbuhan dan Profitabilitas Terhadap Struktur Modal: Studi Empiris Pada Perusahaan Sektor Pertambangan yang Listing di Bursa Efek Indonesia Periode 2004-2007". Jurnal Ilmiah Akuntansi, Vol.2, No.6, pp.1-23.

Sanusi, A. (2013). Metodologi Penelitian Bisnis. Edisi Ketiga. Jakarta: Salemba Empat.

Sartono, R. A. (2015). Manajemen Keuangan Teori dan Aplikasi. Edisi Keempat. Yogyakarta: BPFE.

Situmorang, S. H., dan Lufti, M. (2014). Analisis Data untuk Riset Manajemen dan Bisnis. Edisi Ketiga. Medan: USU Press.

Sugiyono. (2010). Statistika Untuk Penelitian. Bandung: Alfabeta. Syahyunan. (2015). Manajemen Keuangan Perencanaan Analisis dan Pengendalian Keuangan. Edisi Kedua. Medan: USU Press.

Ting, I. W., end Lean, H. H. (2011). "Capital Structure of Government-Linked Companies in Malaysia." Asian Academy of Management Journal of Accounting and Finance, Vol. 7, No. 2, pp.137-156.

Trin, T. H., end Phuong, N. T. (2016). "Effect of Financial Crisis on Capital Structure of Listed Firms in Vietnam." International Journal of Financial Research, Vol.7, No. 1, pp.66-74. 